\title{
Characterization of Slag Cement Mortar Containing Nonthermally Treated Dried Red Mud
}

\author{
Gyeongcheol Choe ${ }^{1} \oplus$, Sukpyo Kang ${ }^{2, *}$ and Hyeju Kang ${ }^{2}$ \\ 1 Department of Architectural Engineering, Chungnam National University, 99 Daehak-ro, Yuseong-gu, \\ Daejeon 34134, Republic of Korea; choegc@cnu.ac.kr \\ 2 Department of Architecture, Woosuk University, Jincheon 27841, Republic of Korea; leekang02@nate.com \\ * Correspondence: ksp0404@woosuk.ac.kr
}

Received: 30 May 2019; Accepted: 18 June 2019; Published: 20 June 2019

\begin{abstract}
In this study, a method was suggested to produce dried powder from red mud (RM) sludge with $40 \%-60 \%$ water content without heating. The RM sludge is discharged from the Bayer process, which is used to produce alumina from bauxite ores. Nonthermally treated RM (NTRM) powder was produced by mixing RM sludge (50\%), paper sludge ash (PSA, 35\%), and high-calcium fly ash (HCFA, 15\%). The physicochemical properties of NTRM were investigated by analyzing its water content, X-ray fluorescence spectra, X-ray diffraction patterns, and particle size. Moreover, to examine the applicability of NTRM as a construction material, slag cement mortar in which $20 \mathrm{wt} \%$ of the binder was replaced with NTRM was produced, and the compressive strength, porosity, and water absorption rate of the mortar were evaluated. Results indicated that NTRM of acceptable quality was produced when the water content in RM sludge decreased and $\mathrm{CaO}$ contained in PSA and HCFA reacted with moisture and formed portlandite. The NTRM-mixed mortar requires further examination in terms of durability because of the increased capillary voids and high water absorption rate, but its compressive strength is sufficient to enable its use in sidewalks, bike roads, and parking lots.
\end{abstract}

Keywords: red mud; bauxite; slag cement; paper sludge ash; high-calcium fly ash

\section{Introduction}

Sustainable development of an industry depends on effective treatment of industrial wastes and conservation of natural resources. Therefore, it is important to transform industrial wastes into raw materials that can replace natural resources [1]. Red mud (RM) is an industrial byproduct generated from the Bayer process, which is used to produce alumina, and is one of the most commonly generated industrial byproducts in modern society [2]. Production of 1 ton of alumina generates 1.0-1.5 tons of RM [3]. Growth of the aluminum industry has increased the number of factories, and it is estimated that 1.2 million tons of RM is being generated every year, and 4 billion tons of RM has been generated worldwide as of 2015.

RM discharged from the Bayer process is an insoluble solid that exhibits high alkalinity ( $\mathrm{pH}$ 10-12.5) because of the influence of caustic soda, which is added in the course of extracting alumina from bauxite ores [4]. Dumping of RM in the sea or in open yards may cause various environmental problems, and landfills can reach their limits because of such dumping [1,3]. Therefore, new RM treatment methods are required for sustainable growth of the aluminum industry $[3,5]$

Use of industrial byproducts as construction materials is one of the good methods to reuse such byproducts in large quantities [6,7]. Efforts have been made in various fields to use RM as a construction material. For example, Tsakiridis et al. [8] produced cement through sintering at $1450{ }^{\circ} \mathrm{C}$ using RM as a raw material. Senff et al. [7] examined the rheology and curing characteristics of cement mortar containing RM. Villarejo et al. [9] attempted to produce ceramics by replacing clay with RM and 
proposed optimal conditions for the RM substitution rate, sintering temperature, and sintering time. Ribeiro et al. [10] examined a method of utilizing RM in the production of ordinary Portland cement (OPC) mortar, and they reported that the workability of mortar decreased because of the addition of RM, but the water absorption rate could decrease and the compressive strength could increase when the RM substitution rate was $20 \%$ or less. Liu and Poon [11] confirmed that the addition of RM into self-compacting mortar had various benefits such as an increase in compressive and tensile strengths and a decrease in drying shrinkage. Moreover, Geng et al. [12] examined the production of geopolymers using RM.

As described above, many researchers have made efforts to use RM as a construction material, but there are still several limitations in the production process used for such a material. In the production of ceramics using RM, an increase in the amount of RM leads to benefits such as an increase in the compressive strength of ceramics and a decrease in the water absorption rate because the presence of RM increases the vitreous phase in the ceramic matrix; however, the firing process used in production requires a high temperature of more than $900^{\circ} \mathrm{C}$ [7]. In most studies that used $\mathrm{RM}$ as a base material for binders or geopolymers, dried RM powder was used. However, RM in the Bayer process is discharged in a slurry state with $40 \%-60 \%$ water content. Because water content in the RM sludge varies depending on the storage location or period, appropriate management of water content is necessary to use RM as a raw material [13]. Therefore, RM is turned into powder through a high-temperature drying process, which requires additional energy input. The cost increase resulting from this energy-intensive pretreatment process may act as another obstacle to the use of RM as a construction material [14].

Therefore, technology is required that can convert RM into a construction material using minimal energy input. This study attempted to develop a method of controlling the water content in RM sludge without heat treatment. The method of removing moisture without heating is based on the principle of using soil stabilizers to stabilize the soft ground. It is possible to reduce moisture in soil by inducing formation of hydration products through mixing of inorganic powder (e.g., Portland cement) that facilitates the hydration reaction with soil. Various industrial byproducts having $\mathrm{MgO}$ or $\mathrm{CaO}$ are currently being used as soil stabilizers.

This study attempted to reduce the moisture in RM sludge without heat treatment by mixing $\mathrm{CaO}$ with the RM sludge. Nonthermally treated dried red mud (NTRM) was produced by mixing RM sludge, Paper sludge ash (PSA), and high-calcium fly ash (HCFA). PSA and HCFA were used to supply $\mathrm{CaO}$. Changes in water content, $\mathrm{X}$-ray fluorescence (XRF) spectra, $\mathrm{X}$-ray diffraction (XRD) patterns, and particle size of NRTM were analyzed over time, and results were compared with those of the conventionally used dried RM powder. Moreover, NTRM was added to slag cement mortar, and the characteristics of this mortar were experimentally analyzed to examine the possibility of converting $\mathrm{RM}$ into a construction material.

\section{Nonthermally Treated Dried Red Mud (NTRM) Manufacturing}

\subsection{Raw Materials}

Table 1 lists the chemical composition of raw materials used in the manufacturing of NTRM. The RM sludge used in this study was produced from the Bayer process. Its water content was $50 \%$, and its viscosity was $10,000 \mathrm{cP}$. $\mathrm{SiO}_{2}, \mathrm{Al}_{2} \mathrm{O}_{3}, \mathrm{Fe}_{2} \mathrm{O}_{3}$, and $\mathrm{Na}_{2} \mathrm{O}$, which are major oxides, accounted for more than $87 \%$ of the total mass. As previously stated, the water content of red mud sludge emitted in the Bayer process varies in the range of $40 \%-60 \%$. The amount of water in RM sludge can affect the water content in NTRM. Therefore, in this study, RM sludge with constant water content (50\%) was used to avoid the influence of water content. 
Table 1. Chemical composition of raw materials.

\begin{tabular}{cccc}
\hline \multirow{2}{*}{ Element Oxide } & \multicolumn{3}{c}{ Content (mass\%) } \\
\cline { 2 - 4 } & Red Mud (RM) Sludge & Paper Sludge Ash (PSA) & High-Calcium Fly Ash (HCFA) \\
\hline $\mathrm{SiO}_{2}$ & 38.80 & 17.00 & 26.70 \\
$\mathrm{Al}_{2} \mathrm{O}_{3}$ & 16.10 & 9.83 & 13.10 \\
$\mathrm{Fe}_{2} \mathrm{O}_{3}$ & 22.80 & 6.77 & 8.71 \\
$\mathrm{MgO}$ & 0.20 & 4.05 & 4.40 \\
$\mathrm{Na} O$ & 10.00 & - & - \\
$\mathrm{CaO}$ & 3.40 & 59.70 & 41.20 \\
$\mathrm{TiO}_{2}$ & 2.40 & 0.39 & - \\
$\mathrm{SO}_{3}$ & 0.24 & 1.80 & 5.28 \\
& & & \\
& & & \\
\end{tabular}

In South Korea, the amount of paper sludge generated is approximately 1.6 million tons per year, and $20 \%-30 \%$ of it is estimated to be converted into PSA, which can be clay based or lime based depending on the additive type. Because the additive used in South Korea is mainly limestone, $\mathrm{Al}_{2} \mathrm{O}_{3}$, $\mathrm{SiO}_{2}$, and $\mathrm{CaO}$ represent more than $50 \%$ of the total mass. For PSA used in this study, the $\mathrm{CaO}$ content was $59.70 \%$, and the content of $\mathrm{Al}_{2} \mathrm{O}_{3}, \mathrm{SiO}_{2}$, and $\mathrm{CaO}$, which are major oxides, was $86.53 \%$.

HCFA is one of the byproducts generated in thermal power plants that use a circulating fluidized bed. It is produced from maintaining the combustion temperature at approximately $850{ }^{\circ} \mathrm{C}$ and spraying ammonia to prevent discharge of nitrogen oxides from power plants. In South Korea, 400,000 tons of HCFA is generated each year, but the entire amount is being landfilled instead of being used as an admixture for concrete and as a raw material for cement because it fails to meet the Korean industrial standard (KS L0 5405) $[15,16]$. For HCFA used in this study, the major oxides were $\mathrm{Al}_{2} \mathrm{O}_{3}$, $\mathrm{SiO}_{2}$, and $\mathrm{CaO}$ as in the case of PSA, and the $\mathrm{CaO}$ content was $41.20 \%$.

\subsection{Experimental Plan to Manufacture NTRM}

Table 2 presents the experimental plan for the manufacturing of NTRM. It consisted of RM sludge $(50 \%)$, PSA (35\%), and HCFA (15\%), which were mixed for 4 min using an asphalt mixer for the experiments. As the mixture that was discharged from the asphalt mixer was condensed in the shape of balls, they were crushed into powder using a pin mill at $1500 \mathrm{rpm}$.

Table 2. Experimental plan and mixture proportion to manufacture nonthermally treated dried red mud (NTRM).

\begin{tabular}{cccc}
\hline Materials & Proportion $\mathbf{( w t} \%)$ & Mixing Method & Measured Parameters \\
\hline RM sludge & 50 & Mixer type: & Water content \\
PSA & 35 & Asphalt mixer & Particle size \\
HCFA & 15 & Mixing time: 4 min & XRF spectra \\
& & & XRD patterns \\
\hline
\end{tabular}

To investigate the characteristics of NTRM, the water content, particle size, XRF spectra, and XRD patterns were analyzed. Measurement results of NTRM were compared with the dried RM through heating. The water content was measured 2, 12, 24, 48, 72, 96, and $120 \mathrm{~h}$ after completion of mixing. 
The mass of the sample before and after drying was measured, and the measured values were used to calculate the water content using Equation (1).

$$
\text { Water content }(\%)=\frac{\text { Weight of undried } \operatorname{NTRM}(g)-\text { Weight of dried } \operatorname{NTRM}(g)}{\text { Weight of undried } \operatorname{NTRM}(g)} \times 100
$$

The particle size distributions of NTRM and RM were examined using a Particle size analyzer (Mastersizer 3000-Maz6140, Malvern Instruments Ltd., Malvern, UK). The XRF spectrometer (ZSX Primus IV, RIGAKU, Tokyo, Japan) was used to assess the chemical compositions of NTRM and RM. The XRD patterns for NTRM and RM were collected using an X-ray Diffractometer (Smartlab, RIGAKU, Tokyo, Japan) The diffraction patterns were obtained at $2 \theta$ from $5^{\circ}$ to $65^{\circ}$ in steps of $0.01^{\circ}$, with each step lasting $1 \mathrm{~s}$. The divergence slit was $0.3^{\circ}$, while the soller slit was $2.5^{\circ}$.

\subsection{Characteristics of NTRM}

\subsubsection{Water Content}

Figure 1 shows the water content in NTRM with aging time. The water content in NTRM immediately after mixing could be estimated to be $25 \%$ of the total mass considering the water content and mixture proportion of the RM sludge. The water content in NTRM decreased to $20 \% 2 \mathrm{~h}$ after completion of mixing and to $14 \%$ after $24 \mathrm{~h}$. The water content was significantly low for $24 \mathrm{~h}$ after completion of mixing, and it decreased by approximately $3 \%$ from 24 to $96 \mathrm{~h}$. A mere $0.4 \%$ decrease in water content was observed in the $24 \mathrm{~h}$ period from 96 to $120 \mathrm{~h}$, and the water content exhibited a tendency to converge to approximately $11 \%$. It was possible to produce NTRM with an $11 \%$ water content from RM sludge with a 50\% water content without heating by mixing the RM sludge with PSA and HCFA.

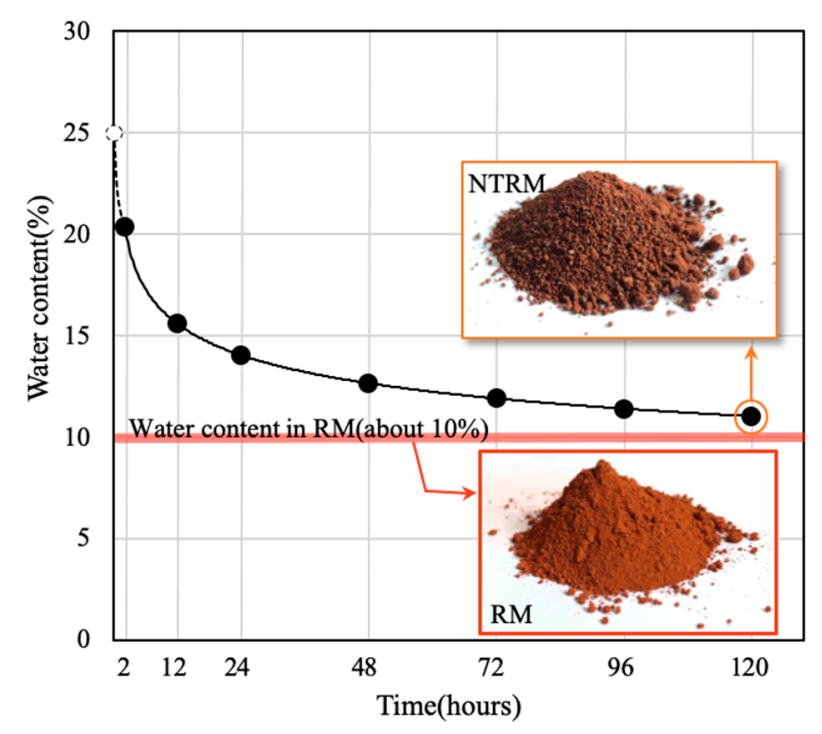

Figure 1. Water content in NTRM with aging time.

\subsubsection{Chemical Properties}

Figure 2 compares the oxide chemical compositions of NTRM obtained using XRF analyses with those of RM. In general, the components of RM are similar regardless of the production areas of the raw materials, but the component proportions in RM are known to be significantly different depending on the production method of aluminum or the production area of bauxite ores $[4,17,18]$. The RM used in this study consisted of $\mathrm{SiO}_{2}, \mathrm{Al}_{2} \mathrm{O}_{3}, \mathrm{Fe}_{2} \mathrm{O}_{3}, \mathrm{MnO}, \mathrm{MgO}, \mathrm{CaO}, \mathrm{Na}_{2} \mathrm{O}, \mathrm{K} 2 \mathrm{O}, \mathrm{TiO}_{2}, \mathrm{P}_{2} \mathrm{O}_{5}$, and $\mathrm{SO}_{3}$, and its major oxides were $\mathrm{Fe}_{2} \mathrm{O}_{3}, \mathrm{Al}_{2} \mathrm{O}_{3}, \mathrm{SiO}_{2}$, and $\mathrm{CaO}$. These four oxides accounted for $87 \%$ of the total mass. 


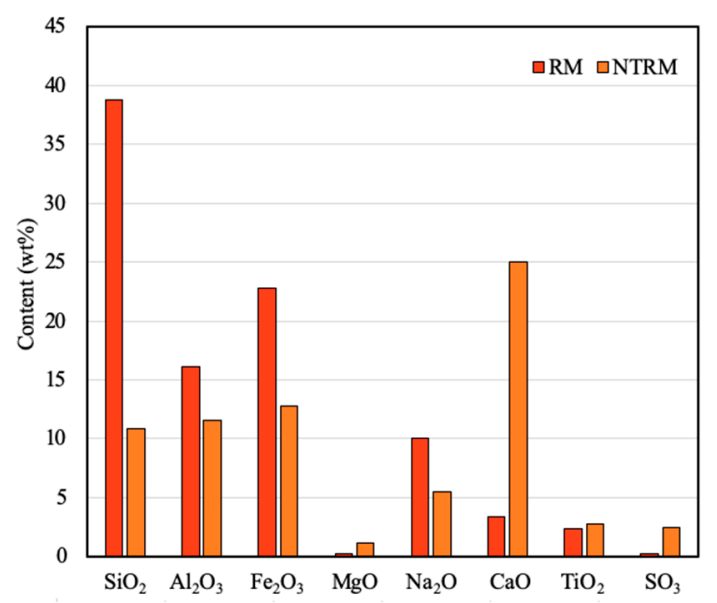

Figure 2. Oxide chemical compositions of RM and NTRM.

The chemical composition of NTRM was not considerably different from that of RM, but a slight difference in component proportions was observed. $\mathrm{SiO}_{2}, \mathrm{Al}_{2} \mathrm{O}_{3}, \mathrm{Fe}_{2} \mathrm{O}_{3}$, and $\mathrm{Na}_{2} \mathrm{O}$ proportions for NTRM were $28.00 \%, 5.50 \%, 10.00 \%$, and $4.51 \%$ lower, respectively, than those for RM. However, the $\mathrm{CaO}$ proportion for NTRM was $21.60 \%$ higher than that for RM. It appeared that NTRM had a higher proportion of $\mathrm{CaO}$ because the PSA and HCFA used for production of NTRM had high proportions of $\mathrm{CaO}(59.70 \%$ and $41.20 \%$, respectively).

Figure 3 shows the XRD patterns of RM and NTRM. RM included iron oxides such as hematite $\left(\mathrm{Fe}_{2} \mathrm{O}_{3}\right)$; titanium oxides such as perovskite $\left(\mathrm{CaTiO}_{3}\right)$, rutile $\left(\mathrm{TiO}_{2}\right)$, and anatase $\left(\mathrm{TiO}_{2}\right)$; and aluminum oxides such as boehmite $(\mathrm{AlO}(\mathrm{OH}))$. It also included quartz $\left(\mathrm{SiO}_{2}\right)$ and calcite $\left(\mathrm{CaCO}_{3}\right)$. The minerals in NTRM, which were very similar to those in $\mathrm{RM}$, included hematite $\left(\mathrm{FeO}_{3}\right)$, boehmite $(\mathrm{AlO}(\mathrm{OH}))$, rutile $\left(\mathrm{TiO}_{2}\right)$, quartz $\left(\mathrm{SiO}_{2}\right)$, calcite $\left(\mathrm{CaCO}_{3}\right)$, and portlandite $\left(\mathrm{Ca}(\mathrm{OH})_{2}\right)$. Note that NTRM included portlandite, which was not found in RM. These observations confirmed that $\mathrm{Ca}(\mathrm{OH})_{2}$, which was a hydration product, was produced from the reaction between the moisture in $\mathrm{RM}$ sludge and the $\mathrm{CaO}$ in PSA and HCFA.

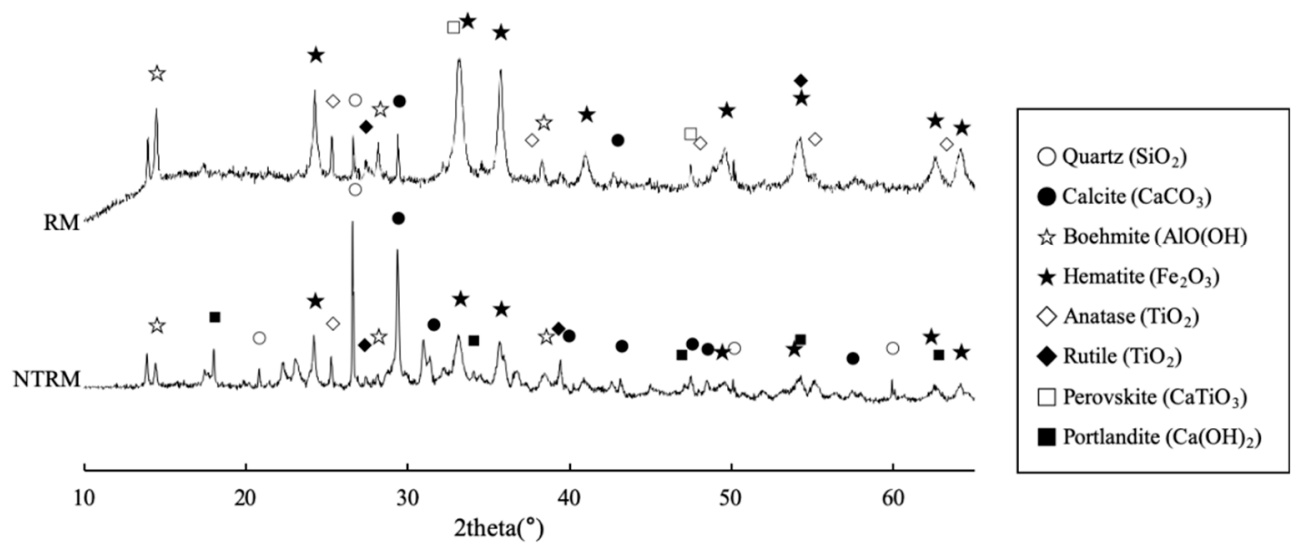

Figure 3. XRD patterns of RM and NTRM.

\subsubsection{Particle Size}

Figure 4 shows the particle size distribution of RM and NTRM. For comparison purposes, the particle size distribution of OPC is also shown in the graphs. The specific surface area and average grain diameter of RM were $2353 \mathrm{~m}^{3} / \mathrm{kg}$ and $2.75 \mu \mathrm{m}$, respectively, and its Dv10, Dv50, and Dv90 values were 1.4, 5.5, and $43.0 \mu \mathrm{m}$, respectively. Its average particle diameter was smaller than that of OPC. In the frequency distribution curve for RM, three peaks were seen, which were not seen in the corresponding curve for OPC. 

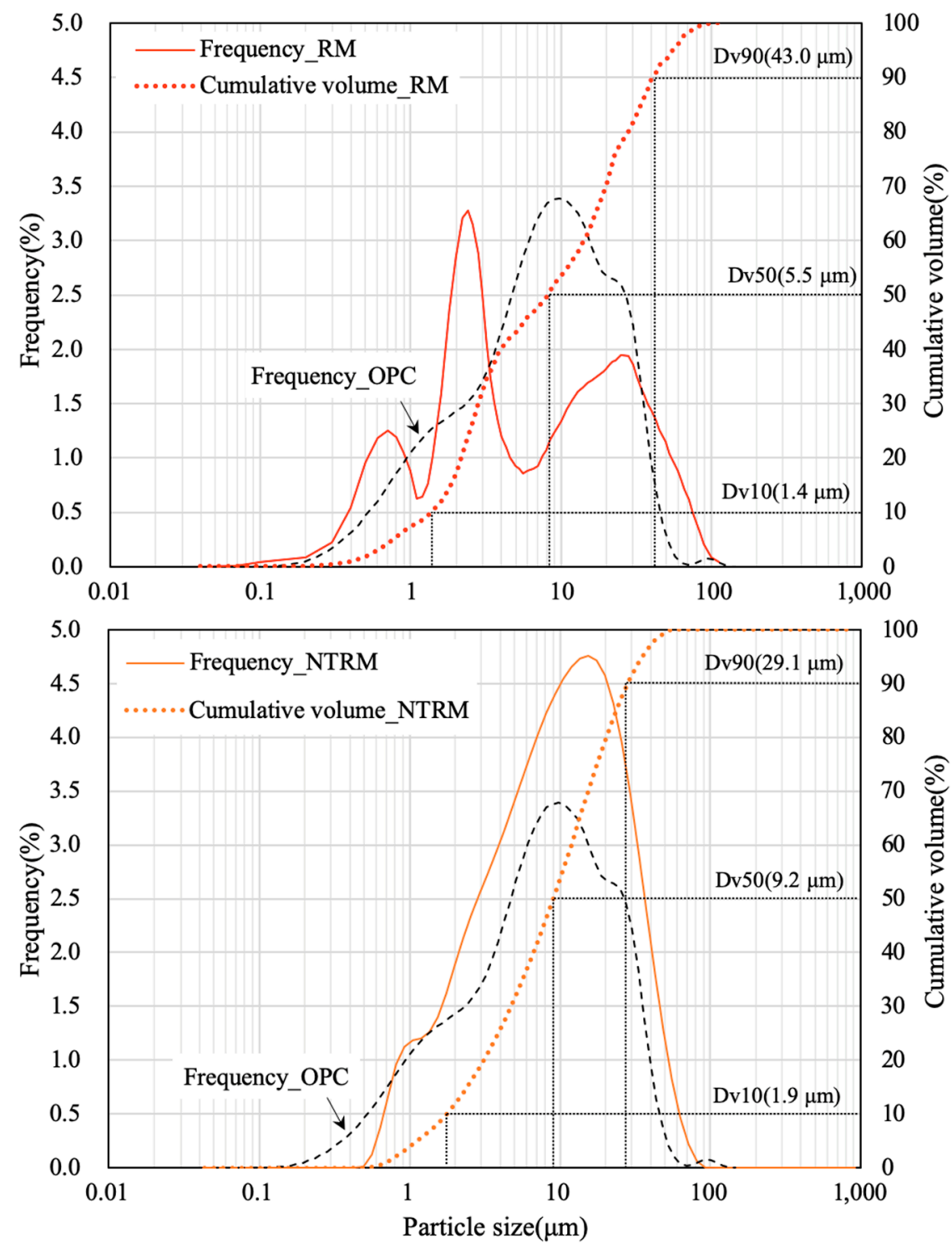

Figure 4. Particle size distribution of RM and NTRM.

The specific surface area and average grain diameter of NTRM were $1260 \mathrm{~m}^{2} / \mathrm{kg}$ and $9.66 \mu \mathrm{m}$, respectively, and its Dv10, Dv50, and Dv90 values were 1.9, 9.2, and $29.1 \mu \mathrm{m}$, respectively. Its frequency distribution curve had a very similar shape to that of OPC, but its average particle diameter was larger than that of OPC. The specific surface area of NTRM was 50\% smaller than that of RM, and the average grain diameter of NTRM was 3.5 times that of RM.

\section{Characterization of Slag Cement Mortar Containing RM and NTRM}

\subsection{Materials}

Previous studies [19-21] confirmed that RM that includes $\mathrm{NaO}_{2}$ may act as an activator of slag-based binders because of its high alkalinity. Therefore, in this study, slag cement (SC) obtained by mixing type 1 OPC and ground-granulated blast-furnace slag at a 50:50 ratio was used as a mortar binder. Table 3 lists the physical properties and chemical compositions of the type 1 OPC and ground granulated blast-furnace slag. ISO standard sand was used as the fine aggregate [22]. 
Table 3. Physical properties and chemical compositions of binder.

\begin{tabular}{|c|c|c|c|c|c|c|c|c|c|}
\hline \multirow{2}{*}{ Type $^{1}$} & \multirow{2}{*}{$\begin{array}{l}\text { Specific Surface } \\
\text { Area }\left(\mathrm{cm}^{2} / \mathrm{g}\right)\end{array}$} & \multirow{2}{*}{$\begin{array}{l}\text { Density } \\
\left(\mathrm{g} / \mathrm{cm}^{3}\right)\end{array}$} & \multirow{2}{*}{ Lg. Loss } & \multicolumn{6}{|c|}{ Chemical Composition (\%) } \\
\hline & & & & $\mathrm{SiO}_{2}$ & $\mathrm{Al}_{2} \mathrm{O}_{3}$ & $\mathrm{Fe}_{2} \mathrm{O}_{3}$ & $\mathrm{CaO}$ & $\mathrm{MgO}$ & $\mathrm{SO}_{3}$ \\
\hline OPC & 3.144 & 3.15 & 2.44 & 21.7 & 5.7 & 3.2 & 63.1 & 2.8 & 2.2 \\
\hline GGBS & 4196 & 2.90 & 1.32 & 32.75 & 15.61 & 0.5 & 43.51 & 4.41 & - \\
\hline
\end{tabular}

\subsection{Experimental Outline}

Table 4 presents the experimental plan and mixture proportion of mortar to evaluate the possibility of NTRM as construction materials. Depending on the RM mixing conditions, three types of specimens (i.e., SC100, SC80RM20, and SC80NTRM20) were prepared. The binder and aggregate were set at a 1:3 ratio based on the mass. NTRM and RM were added such that they replaced $20 \%$ of the slag cement. Since the aim of this chapter was to review the possibility of NTRM as a construction material, a compressive strength test was conducted to assess mechanical properties. Porosity and water absorption tests were conducted to estimate the microstructure formation of mortar. Figure 5 shows test setups for compressive strength and water absorption. Three specimens of each type were prepared for each test.

Table 4. Experimental plan and mixture proportion of mortar.

\begin{tabular}{cccccccc}
\hline \multirow{2}{*}{ Specimen ID } & \multirow{2}{*}{ W/B ${ }^{\mathbf{1}}$} & \multirow{2}{*}{ B:S $^{2}$} & \multicolumn{3}{c}{ Binder (wt\%) } & \multirow{2}{*}{ Measured Parameters } \\
\cline { 4 - 6 } & & & SC & RM & NTRM & \\
SC100 & & & 100 & - & - & Compressive strength (MPa) \\
SC80RM20 & 0.6 & $1: 3$ & 80 & 20 & - & $\begin{array}{c}\text { Porosity } \\
\text { SC80NTRM20 }\end{array}$ \\
\hline
\end{tabular}

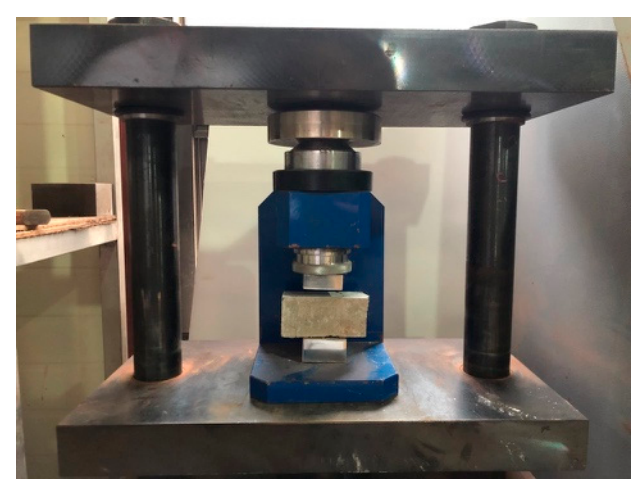

(a)

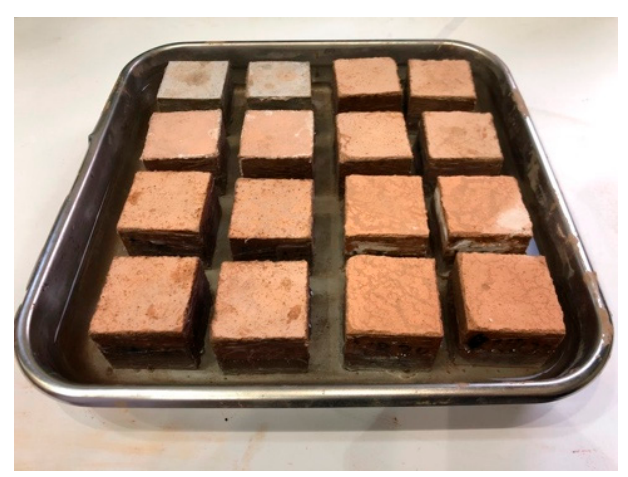

(b)

Figure 5. Test setup of (a) compressive strength and (b) water absorption.

\subsection{Experimental Method}

\subsubsection{Compressive Strength}

Beam mortar samples $(40 \mathrm{~mm} \times 40 \mathrm{~mm} \times 160 \mathrm{~mm})$ were prepared and cured under room conditions (temperature: $20 \pm 2{ }^{\circ} \mathrm{C}$ and relative humidity: $60 \pm 5 \%$ ). After curing for $1,3,7$, and 28 days, the compressive strength was evaluated according to ASTM C 349 [23]. 


\subsubsection{Porosity}

Mercury intrusion porosimetry (MIP) measurements were performed using cubic pieces $\left(5 \mathrm{~mm} \times 5 \mathrm{~mm} \times 5 \mathrm{~mm}\right.$, volume: $\left.125 \mathrm{~mm}^{3}\right)$ obtained from the central inner part of hardened samples. These pieces were immersed in isopropyl alcohol for 4 weeks to prevent further hydration. After 4 weeks, the samples were dried in a vacuum desiccator for 2 days to eliminate any residual solvent inside the samples. A mercury porosimeter (Autopore IV, Micromeritics, GA, USA) was used for MIP measurements.

\subsubsection{Water Absorption Coefficient}

Construction materials with a porosity like that of cement mortar can absorb water through capillary suction. Initially, a large amount of water is absorbed, and the absorption later becomes steady. The absorption coefficient was obtained based on KS F 2609 [24] according to the following equation:

$$
m=w \cdot \sqrt{t}
$$

where $m$ is the amount of water absorption $\left(\mathrm{kg} / \mathrm{m}^{2}\right), t$ is the test period $(\mathrm{h})$, and $w\left(\mathrm{~kg} / \mathrm{m}^{2} \cdot \mathrm{h}^{1 / 2}\right)$ is the water absorption coefficient.

\subsection{Experimental Results and Discussion}

\subsubsection{Compressive Strength}

Figure 6 and Table 5 show the compressive strengths of SC100, SC80RM20, and SC80NTRM20. For all curing ages, SC100 had the highest compressive strength, and SC80NTRM20 had the lowest value. On the first day, the measured compressive strength was $6.26 \mathrm{MPa}$ for SC100, 5.02 MPa for SC80RM20, and $3.95 \mathrm{MPa}$ for SC80NTRM20. After 28 days, the compressive strengths of SC100, SC80RM20, and SC80NTRM20 were 30.14, 25.91, and $19.98 \mathrm{MPa}$, respectively, indicating that the differences in the compressive strength increased as the age increased. This tendency of decreasing compressive strength owing to the addition of RM was the same as the tendency reported in other previous studies [25-29]. However, this tendency was significantly different from that reported by Ribeiro et al. [10], who found that the density and compressive strength increased as the RM addition amount increased. This difference may have occurred because the RM used in this study had larger particle sizes than the RM used in the study of Ribeiro et al. [10], and thus, the pore filling was not sufficient to increase the compressive strength.

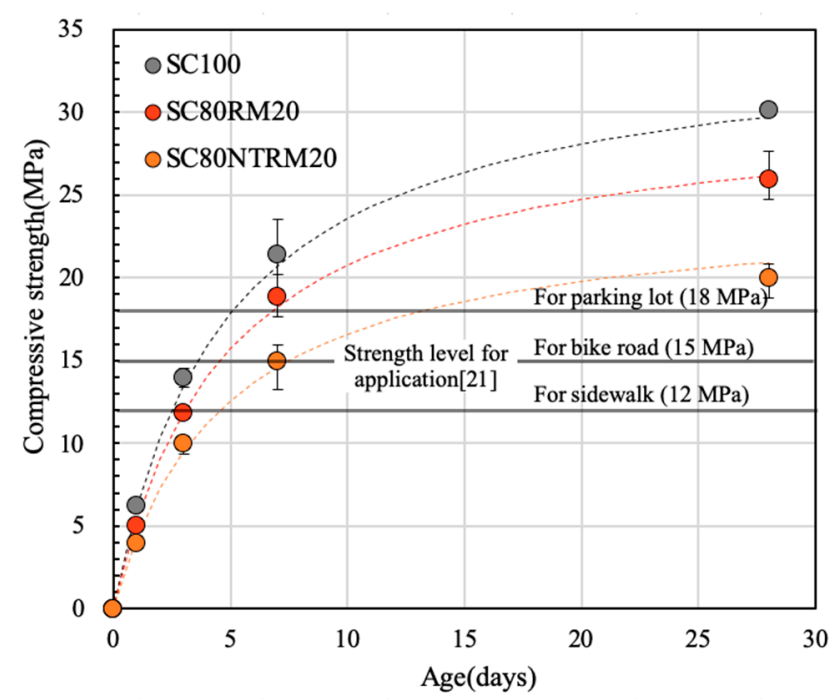

Figure 6. Compressive strength of different RM-type mortar specimens. 
Table 5. Compressive strength data of different RM-type mortar specimens.

\begin{tabular}{ccccccc}
\hline \multirow{2}{*}{ Specimen ID } & \multirow{2}{*}{ Age (d) } & \multicolumn{5}{c}{ Compressive Strength (MPa) } \\
\cline { 2 - 7 } & & no.1 & no.2 & no.3 & Average & CV $^{\mathbf{1}}$ \\
\hline \multirow{3}{*}{ SC100 } & 1 & 6.24 & 6.34 & 6.19 & 6.26 & 0.07 \\
& 3 & 13.36 & 13.99 & 14.49 & 13.95 & 0.56 \\
& 7 & 23.55 & 18.63 & 21.96 & 21.38 & 2.50 \\
& 28 & 30.08 & 30.53 & 29.81 & 30.14 & 0.35 \\
\hline \multirow{3}{*}{ SC80RM20 } & 1 & 5.18 & 4.87 & 5.01 & 5.02 & 0.15 \\
& 3 & 11.81 & 11.83 & 11.87 & 11.84 & 0.03 \\
& 7 & 20.18 & 17.62 & 18.71 & 18.83 & 1.28 \\
& 28 & 24.74 & 27.67 & 25.33 & 25.91 & 1.55 \\
\hline \multirow{3}{*}{ SC80NTRM20 } & 1 & 4.19 & 3.82 & 3.84 & 3.95 & 0.21 \\
& 3 & 9.31 & 10.28 & 10.26 & 9.95 & 0.55 \\
& 7 & 15.92 & 13.24 & 15.70 & 14.95 & 1.49 \\
& 28 & 20.84 & 18.78 & 20.33 & 19.98 & 1.07 \\
\hline
\end{tabular}

Yao et al. [30] reported that mortar based on a binder, in which RM, coal refuse, fly ash, and OPC were mixed, could achieve a higher compressive strength than OPC mortar on a long-term basis because of pozzolanic reactions. The PSA and HCFA used in this study contained a large amount of CaO, and thus, the compressive strength could be expected to increase because of the hydration reaction. However, it appears that the strength of the mortar could not be increased because the $\mathrm{CaO}$ already present in PSA and HCFA reacted with moisture in the RM sludge during the NTRM production process and generated portlandite $\left(\mathrm{Ca}(\mathrm{OH})_{2}\right)$, as shown in Figure 7. In this study, although SC80NTRM20 had a lower compressive strength than SC100 and SC80RM20, it was confirmed that it had sufficient strength to be used as a raw material for sidewalks, bike roads, and parking lots, as suggested by Kim et al. [21].

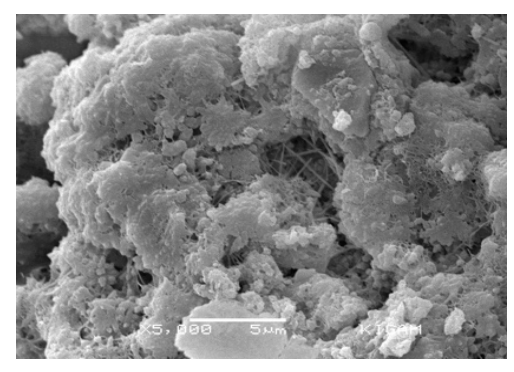

(a)

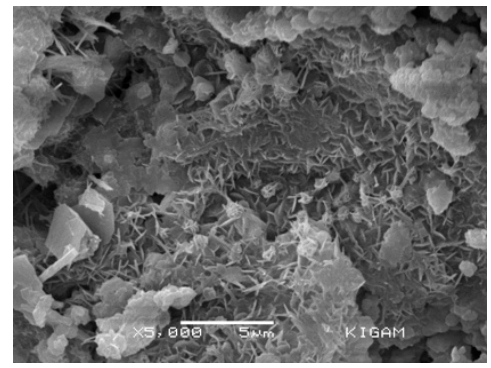

(b)

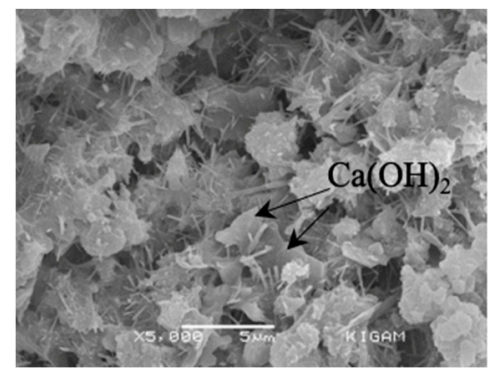

(c)

Figure 7. SEM images of (a) SC100, (b) SC80RM20, and (c) SC80NTRM20 on the first day.

\subsubsection{Porosity}

Figure 8 shows the pore size characteristics of SC100, SC80RM20, and SC80NTRM20. As pore characteristics, the total porosity and pore size distribution were measured. The total porosities of SC100, SC80RM20, and SC80NTRM20 were $17.16 \%, 20.78 \%$, and $22.66 \%$, respectively. The total porosities of SC80RM20 and SC80NTRM20, which included RM, were 3\%-5\% higher than that of SC100. Among the samples, SC80NTRM20 had the highest total porosity.

In the pore size distribution, it was found that there were relatively more pores with the three sizes of 10-100, 1000, and 100,000 nm. In general, pores with 0-1000 nm sizes represent capillary voids, and pores with 100,000 nm sizes represent air bubbles [31]. Pores with 10-100 nm sizes, which correspond to small capillary pores, were found to have the largest distribution in SC80RM20 and the smallest distribution in SC100. Pores with $1000 \mathrm{~nm}$ sizes, which correspond to relatively large capillary voids, were found to have the largest distribution in SC80NTRM20 and the smallest 
distribution in SC100. A previous study [32] reported that pores with sizes larger than $50 \mathrm{~nm}$ affected the compressive strength of mortar. Pores with sizes larger than $50 \mathrm{~nm}$ were found to have the largest distribution in SC80NTRM20, followed by SC80RM20 and SC100. This result was found to be closely related to the results obtained while testing the compressive strength of mortar.

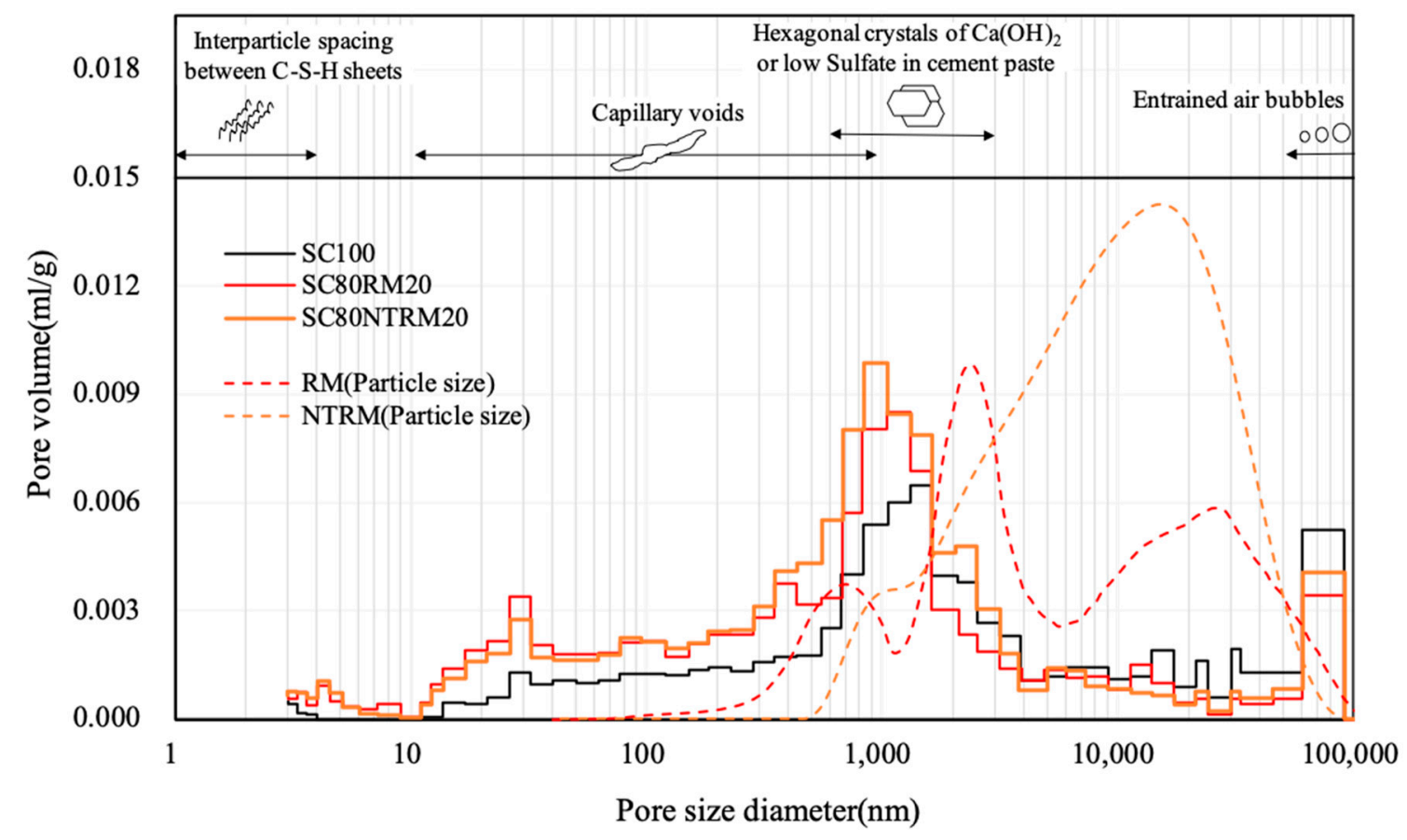

Figure 8. Pore size distributions of SC100, SC80RM20, and SC80NTRM20.

The pore volume of SC80RM20 was the lowest in the 1000-10,000 nm range. As RM had many particles with 1000-10,000 nm sizes, it appeared that these particles exhibited the pore filling effect $[4,10]$. SC80NTRM20 also had the lowest pore volume among the three mortar specimens in the 10,000-100,000 $\mathrm{nm}$ range, where the particle size distribution was the largest. Kim et al. [21] reported that the porosity of mortar decreased because of the pore filling effect of RM microparticles, and this effect was larger for bigger pores.

\subsubsection{Moisture Absorption Coefficient}

Figure 9 shows water absorption rates of the mortar specimens. The water absorption rate linearly increased over time for up to $2 \mathrm{~h}$ for all specimens, but this increase showed a tendency to decrease after $6 \mathrm{~h}$. The water absorption rate was the lowest for SC100 and the highest for SC80NTRM20 over the entire time period.

Figure 10 shows the water absorption coefficients calculated for the quantification of the increase in the water absorption rate over time. The water absorption coefficients of SC100, SC80RM20, and SC80NTRM20 were 0.57, 0.62, and 0.69, respectively, indicating that the specimens with RM had higher water absorption coefficients than the specimen with only slag cement, and the specimen with NTRM had a higher water absorption coefficient than the specimen with RM. Such differences in the water absorption coefficient can be explained using the differences in porosity analyzed previously. Because of the increase in the number of capillary voids, owing to the mixing of RM, the amount of moisture absorbed by the capillary voids increased.

Zhang and Zong [33] reported that it was difficult to find a correlation between the water absorption rate of mortar and its strength. However, according to the present study, results of the capillary void distribution, water absorption rate, and compressive strength of mortar were consistent. 
Therefore, the increase in the number of capillary voids in the mortar can be considered to be the cause of the reduction in the compressive strength and the increase in the water absorption rate.

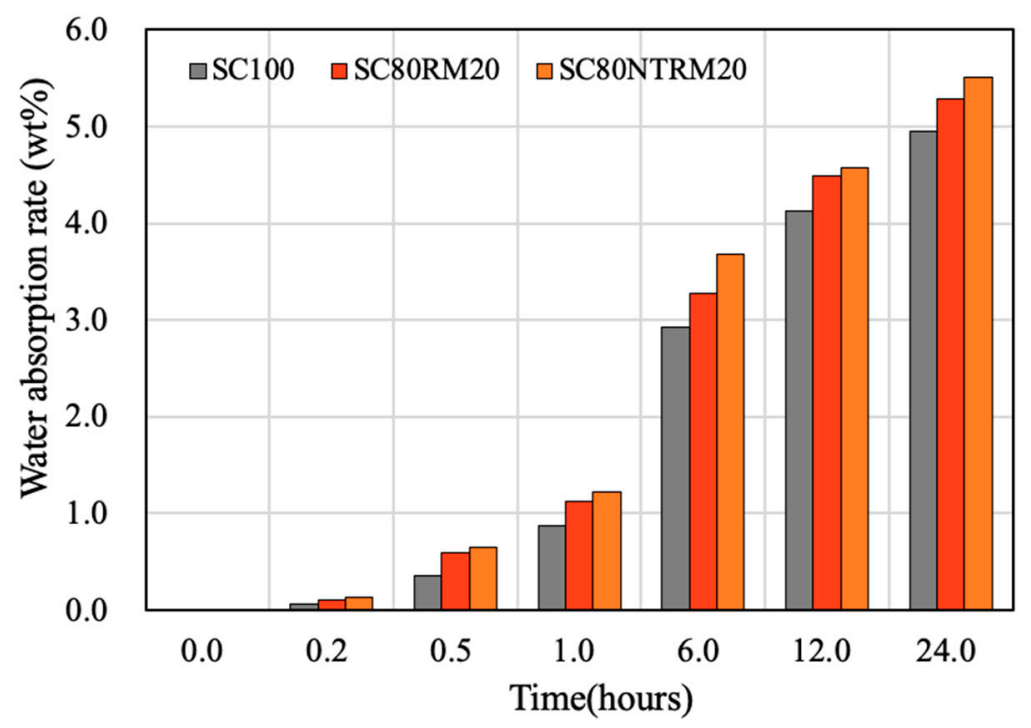

Figure 9. Water absorption rates of SC100, SC80RM20, and SC80NTRM20.

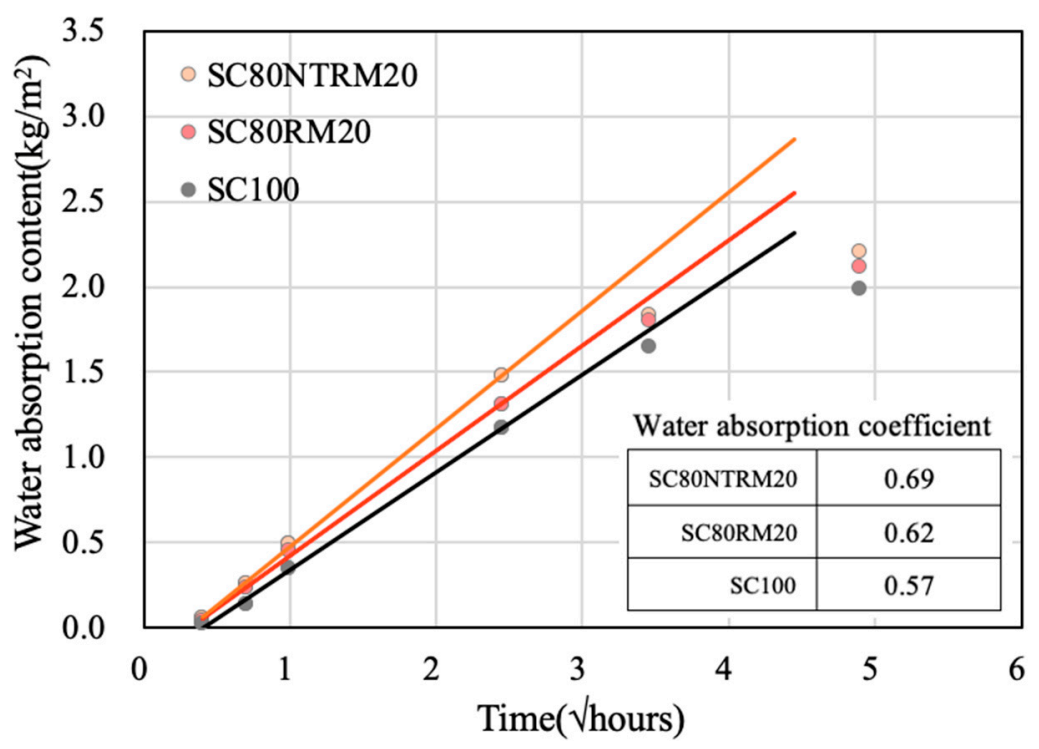

Figure 10. Water absorption coefficients of SC100, SC80RM20, and SC80NTRM20.

Pores can be considered to be either the spaces in the gap between hydrates or the spaces created by water bubbles, and the presence of a number of large pores is known to significantly affect the strength as well as durability of a material. Therefore, it is necessary to examine the durability of RM and NTRM when they are used as construction materials.

\section{Conclusions}

In this study, a method of producing nonthermally treated red mud (NTRM) powder was proposed for economical and efficient recycling of red mud (RM). In the course of mixing RM sludge (50\%), paper sludge ash (PSA, 35\%), and high-calcium fly ash (HCFA, 15\%), CaO contained in the ash-based byproduct reacted with moisture in the RM sludge to form portlandite. Therefore, it was possible to produce RM-based dried powder without heating. 
The compressive strength of the slag cement mortar mixed with NTRM was evaluated to be approximately $65 \%$ of that of the mortar with only slag cement. Although the compressive strength of the slag cement mortar could not be expected to increase because of the mixing of NTRM, it was confirmed that the performance of the mortar mixed with NTRM was sufficient to enable its use in parking lots and road pavements. Therefore, the possibility of using NTRM as a construction material was confirmed.

Because NTRM had only a small number of particles with sizes that could fill capillary voids, which have a significant impact on the compressive strength and durability of a material, the mortar mixed with NTRM had a low compressive strength and a high water absorption rate. Therefore, it is necessary to additionally examine durability when NTRM is used as a construction material.

Author Contributions: Conceptualization, G.C. and S.K.; methodology, H.K.; validation, S.K., G.C., and H.K.; formal analysis, G.C.; investigation, H.K.; resources, H.K.; data curation, G.C.; writing—original draft preparation, G.C.; writing-review and editing, G.C.; visualization, G.C.; supervision, S.K.; project administration, S.K.; funding acquisition, S.K."

Funding: This research was supported by a grant (19CTAP-C142091-02) from Infrastructure and transportation technology promotion research Program funded by Ministry of Land, Infrastructure and Transport of Korean government.

Conflicts of Interest: The authors declare no conflict of interest.

\section{References}

1. Alam, S.; Das, S.K.; Rao, B.H. Characterization of Coarse Fraction of Red Mud as a Civil Engineering Construction Material. J. Clean. Prod. 2017, 168, 679-691. [CrossRef]

2. Mymrin, V.; Guidolin, M.A.; Klitzke, W.; Alekseev, K.; Guidolin, R.H.; Avanci, M.A.; Pawlowsky, U.; Winter, E., Jr.; Catai, R.E. Environmentally Clean Ceramics from Printed Circuit Board Sludge, Red Mud of Bauxite Treatment and Steel Slag. J. Clean. Prod. 2017, 164, 831-839. [CrossRef]

3. Li, J.; Xu, L.; Sun, P.; Zhai, P.; Chen, X.; Zhang, H.; Zhang, Z.; Zhu, W. Novel Application of Red Mud: Facile Hydrothermal-Thermal Conversion Synthesis of Hierarchical Porous $\mathrm{AlOOH}$ and $\mathrm{Al}_{2} \mathrm{O}_{3}$ Microspheres as Adsorbents for Dye Removal. Chem. Eng. J. 2017, 321, 622-634. [CrossRef]

4. Kim, S.Y.; Jun, Y.; Jeon, D.; Oh, J.E. Synthesis of Structural Binder for Red Brick Production Based on Red Mud and Fly Ash Activated Using $\mathrm{Ca}(\mathrm{OH})_{2}$ and $\mathrm{Na}_{2} \mathrm{CO}_{3}$. Constr. Build. Mater. 2017, 147, 101-116. [CrossRef]

5. Mayes, W.M.; Burke, I.T.; Gomes, H.I.; Anton, Á.D.; Molnár, M.; Feigl, V.; Ujaczki, É. Advances in Understanding Environmental Risks of Red Mud after the Ajka Spill, Hungary. J. Sustain. Metall. 2016, 2, 332-343. [CrossRef]

6. Liu, X.; Zhang, N. Utilization of Red Mud in Cement Production: A Review. Waste Manag. Res. 2011, 29, 1053-1063. [CrossRef]

7. Senff, L.; Hotza, D.; Labrincha, J.A. Effect of Red Mud Addition on the Rheological Behaviour and on Hardened State Characteristics of Cement Mortars. Constr. Build. Mater. 2011, 25, 163-170. [CrossRef]

8. Tsakiridis, P.E.; Agatzini-Leonardou, S.; Oustadakis, P. Red Mud Addition in the Raw Meal for the Production of Portland Cement Clinker. J. Hazard. Mater. 2004, 116, 103-110. [CrossRef]

9. Villarejo, L.P.; Corpas-Iglesias, F.A.; Martínez-Martínez, S.; Artiaga, R.; Pascual-Cosp, J. Manufacturing New Ceramic Materials from Clay and Red Mud Derived from the Aluminium Industry. Constr. Build. Mater. 2012, 35, 656-665. [CrossRef]

10. Ribeiro, D.V.; Labrincha, J.A.; Morelli, M.R. Use of Red Mud as Addition for Portland Cement Mortars. J. Mater. Sci. Eng. 2010, 4, 1-9.

11. Liu, R.-X.; Poon, C.S. Utilization of Red Mud Derived from Bauxite in Self-Compacting Concrete. J. Clean. Prod. 2016, 112, 384-391. [CrossRef]

12. Geng, J.; Zhou, M.; Li, Y.; Chen, Y.; Han, Y.; Wan, S.; Zhou, X.; Hou, H. Comparison of Red Mud and Coal Gangue Blended Geopolymers Synthesized through Thermal Activation and Mechanical Grinding Preactivation. Constr. Build. Mater. 2017, 153, 185-192. [CrossRef]

13. Jobbágy, V.; Somlai, J.; Kovács, J.; Szeiler, G.; Kovacs, T. Dependence of Radon Emanation of Red Mud Bauxite Processing Wastes on Heat Treatment. J. Hazard. Mater. 2009, 172, 1258-1263. [CrossRef] [PubMed] 
14. Yang, J.; Xiao, B. Development of Unsintered Construction Materials from Red Mud Wastes Produced in the Sintering Alumina Process. Constr. Build. Mater. 2008, 22, 2299-2307. [CrossRef]

15. KS L 5405 Flyash; Korean Agency for Technology and Standards (KATS): Seoul, Korea, 2009.

16. Kang, S.K. Hydration Characteristics of Coal-Fly Ash Containing High CaO Compound. J. Korean Ceram. Soc. 2012, 49, 185-190. [CrossRef]

17. Pascual, J.; Corpas, F.A.; López-Beceiro, J.; Benítez-Guerrero, M.; Artiaga, R. Thermal Characterization of a Spanish Red Mud. J. Therm. Anal. Calorim. 2009, 96, 407-412. [CrossRef]

18. Yalçin, N.; Sevinç, V. Utilization of Bauxite Waste in Ceramic Glazes. Ceram. Int. 2000, 26, 485-493. [CrossRef]

19. Kang, S.; Kwon, S.-J. Effects of Red Mud and Alkali-Activated Slag Cement on Efflorescence in Cement Mortar. Constr. Build. Mater. 2017, 133, 459-467. [CrossRef]

20. Krivenko, P.; Kovalchuk, O.; Pasko, A.; Croymans, T.; Hult, M.; Lutter, G.; Vandevenne, N.; Schreurs, S.; Schroeyers, W. Development of Alkali Activated Cements and Concrete Mixture Design with High Volumes of Red Mud. Constr. Build. Mater. 2017, 151, 819-826. [CrossRef]

21. Kim, H.; Kaxng, S.; Choe, G. Effect of Red Mud Content on Strength and Efflorescence in Pavement Using Alkali-Activated Slag Cement. Int. J. Concr. Struct. Mater. 2018, 12, 18. [CrossRef]

22. ISO 679: 2009: Cement-Test methods-Determination of Strength; International Organisation for Standardisation: Geneva, Switzerland, 2009.

23. ASTM C 349 Standard Test Method for Compressive Strength of Hydraulic-Cement Mortars (Using Portions of Prisms Broken in Flexure); Annual Book of ASTM: Pennsylvania, PA, USA, 2005.

24. KS F 2609 Determination of the Water Absorption Coefficient of Building Materials; Korean Agency for Technology and Standards (KATS): Seoul, Korea, 2008.

25. Fujii, A.L.; Torres, D.D.R.; Romano, R.C.D.O.; Cincotto, M.A.; Pileggi, R.G. Impact of Superplasticizer on the Hardening of Slag Portland Cement Blended with Red Mud. Constr. Build. Mater. 2015, 101, 432-439. [CrossRef]

26. Senff, L.; Modolo, R.C.E.; Silva, A.S.; Ferreira, V.M.; Hotza, D.; Labrincha, J.A. Influence of Red Mud Addition on Rheological Behavior and Hardened Properties of Mortars. Constr. Build. Mater. 2014, 65, 84-91. [CrossRef]

27. Guo, Y.; Zhang, Y.; Huang, H.; Meng, K.; Hu, K.; Hu, P.; Wang, X.; Zhang, Z.; Meng, X. Novel Glass Ceramic Foams Materials Based on Red Mud. Ceram. Int. 2014, 40, 6677-6683. [CrossRef]

28. Singh, M.; Upadhayay, S.N.; Prasad, P.M. Preparation of Special Cements from Red Mud. Waste Manag. 1996, 16, 665-670. [CrossRef]

29. Lee, S.S.; Song, H.Y.; Lee, Y.S.; Lee, K.P. A Study on the Strength and Flowing Properties of the Non-Cement Inorganic Composite by Using Blast Furnace Slag and Red Mud. Adv. Mater. Res. 2011, 261-263, 491-495. [CrossRef]

30. Yao, Y.; Li, Y.; Liu, X.; Jiang, S.; Feng, C.; Rafanan, E. Characterization on a Cementitious Material Composed of Red Mud and Coal Industry Byproducts. Constr. Build. Mater. 2013, 47, 496-501. [CrossRef]

31. Yang, C.C.; Cho, S.W.; Wang, L.C. The Relationship between Pore Structure and Chloride Diffusivity from Ponding Test in Cement-Based Materials. Mater. Chem. Phys. 2006, 100, 203-210. [CrossRef]

32. Mehta, P.K.; Monteiro, P.J.M. Concrete: Microstructure, Properties, and Materials; McGraw-Hill: New York, NY, USA, 2006; ISBN 0071462899.

33. Zhang, S.P.; Zong, L. Evaluation of Relationship between Water Absorption and Durability of Concrete Materials. Adv. Mater. Sci. Eng. 2014, 2014, 650373. [CrossRef]

(C) 2019 by the authors. Licensee MDPI, Basel, Switzerland. This article is an open access article distributed under the terms and conditions of the Creative Commons Attribution (CC BY) license (http://creativecommons.org/licenses/by/4.0/). 